\title{
Peran Self-Efficacy pada Remaja dalam Menghadapi Stress Sekolah
}

\author{
Inayah Sherly Restika Putri \\ Fakultas Pendidikan Psikologi, Universitas Negeri Malang \\ Jl. Semarang No. 5, Malang, Jawa Timur, Indonesia 65145 \\ inayahsherly008@gmail.com \\ Farah Farida Tantiani \\ Fakultas Pendidikan Psikologi, Universitas Negeri Malang \\ Jl. Semarang No. 5, Malang, Jawa Timur, Indonesia 65145 \\ farah.farida.fppsi@um.ac.id
}

Infromasi Artikel

$\begin{array}{ll}\text { Tanggal masuk } & 24-07-2020 \\ \text { Tanggal revisi } & 15-08-2020 \\ \text { Tanggal diterima } & 17-09-2020\end{array}$

Kata Kunci:

efikasi diri;

remaja;

stress sekolah;

sekolah menengah kejuruan;

korelasi
Abstrak

Penelitian ini bertujuan untuk melihat apakah ada hubungan antara efikasi diri dengan stres sekolah pada siswa sekolah berprestasi di Malang. Diketahui bahwa siswa dapat mengalami stres sekolah ketika mereka merasa tertekan dengan tuntutan tugas, tuntutan guru dan orangtua, dan hubungan interpersonal siswa. Stres sekolah dapat dipengaruhi oleh faktor kepribadian berupa efikasi diri, bila seseorang memiliki efikasi yang rendah maka akan lebih rentan mengalami stres. Penelitian ini merupakan penelitian kuantitatif dengan metode penelitian korelasional. Subjek penelitian ini adalah 145 siswa SMKN 8 Malang. Pengambilan data menggunakan skala efikasi diri (reliabilitas 0,886 dan validitas 0,265 0,628 ) dan skala stres sekolah (reliabilitas 0.786 dan validitas 0,2710,475). Hasil analisis inferensial berupa uji hipotesis dengan menggunakan Pearson product moment menunjukkan hasil berupa nilai koefisien korelasi (rxy) sebesar - 0,504 (sig < 0,05) sehingga disimpulkan bahwa terdapat hubungan yang signifikan dan bersifat negatif antara efikasi diri dengan stres sekolah. Hal ini berarti semakin rendah efikasi diri yang dimiliki maka akan semakin tinggi stres sekolah yang dimiliki begitupun sebaliknya.

Keywords:

self-efficacy;

adolescents;

school stress;

vocational high School;

correlation

\section{Abstract}

This study aims to see whether there is a relationship between selfefficacy and school stress in high school students in Malang. It is known that students can experience school stress when they feel pressured by task demands, teacher and parent demands, and student interpersonal relationships. School stress can be influenced by personality factors such as self-efficacy, if someone has a low efficacy then it will be more susceptible to stress. This research is a quantitative study with a correlational research method. The subjects of this study were 145 students of SMKN 8 Malang. Data collection using self-efficacy scale (reliability 0.886 and validity $0.265-0.662$ ) and school stress scale (reliability 0.786 and validity $0.271-0.475$ ). The results of the inferential analysis in the form of a hypothesis test using Pearson product moment showed the results in the form of a correlation coefficient (rxy) of - 0.504 ( sig $<0.05$ ) so that it was concluded that there was a significant and negative relationship between self-efficacy and school stress. This means that the lower the self-efficacy it has, the higher the school stress it has and vice versa. 


\section{PENDAHULUAN}

Terdapat survei dari American Psychological Association (APA) yang menunjukkan bahwa dari 1.950 orang dewasa dan 1.081 siswa remaja di Amerika, menunjukkan bahwa siswa remaja memiliki tingkat stres yang lebih tinggi terutama pada saat mereka berada pada musim sekolah. Hal tersebut ditunjukkan dengan dari skla 1-10 siswa remaja berada pada rentang 5,8 sedangkan orang dewasa berada pada rentang 5,1 (Bethune, 2014). Selain itu terdapat survei lain di Indonesia yang menunjukkan bahwa $44 \%$ siswa merasa stres pada saat menghadapi tugas dan ujian di sekolah serta $12 \%$ yang lainnya mengalami stres akibat adanya rasa takut akan tidak naik kelas (Maharani, 2015). Siswa lebih banyak menghabiskan waktunya di sekolah dimana hal tersebut dijelaskan dalam Permendikbud 23/2017 dan Perpres $87 / 2017$ bahwa siswa kurang lebih menghabiskan waktu selama 8 jam per hari dalam 5 hari ataupun hingga 6 hari (Ihsanuddin, 2017). Cukup panjangnya waktu yang dihabiskan di sekolah oleh siswa dapat menyebabkan mereka rentan mengalami stres yang bersumber dari lingkungan sekolahnya.

Sekolah yang memiliki prestasi yang baik selama bertahun-tahun seringkali memiliki tuntutan yang lebih kepada siswanya. Menurut Kemendikbud RI, SMA dan sederajat di Kota Malang yang memiliki prestasi IIUN (Indeks Integritas Ujian Nasional) Tertinggi selama 6 tahun berturut-turut merupakan SMKN 8 Malang yang menduduki peringkat pertama. berdasarkan wawancara dengan guru bimbingan konseling dan visi yang dimiliki sekolah selain adanya pembelajaran akademis dan vokasi juga terdapat kewajiban bagi setiap siswa untuk memiliki sertifikat profesi serta setiap siswa wajib menerapkan nilai-nilai agama dan kepedulian terhadap budaya lingkungan sekolah. Hal tersebut dapat menyebabkan siswa mengalami stres sekolah. Dimana stres sekolah menurut
Desmita (2017) merupakan keadaan tertekan atau perasaan tidak nyaman yang dialami oleh siswa yang berasal dari adanya tuntutan sekolah yang dinilai menekan, sehingga memunculkan terjadinya ketegangan fisik, psikologis, dan perubahan tingkah laku sehingga dapat mempengaruhi prestasi belajar dari siswa. Stres sekolah dapat berasal dari keadaan lingkungan fisik sekolah, tuntutan tugas, tuntutan peran, dan tuntutan interpersonal. Adapun siswa yang memiliki tingkat stres yang tinggi akan cenderung berbicara bahkan menentang dibelakang guru, dan membuat canda gurau atau kekacauan di kelas.

Stres yang dimiliki seseorang dapat dihindari, dihadapi, dan diturunkan ketika mereka memiliki keyakinan di dalam dirinya. Keyakinan diri atau efikasi diri menurut Bandura (dalam Feist \& Feist, 2014) dipengaruhi oleh beberapa hal yang mana salah satunya berupa kondisi fisik dan emosional, apabila emosi yang dimiliki seseorang kuat biasanya dapat mempengaruhi tinggi rendah performa seseorang. Emosi yang muncul biasanya seperti seseorang mengalami kecemasan akut, ketakutan yang kuat, atau tingkat stres yang tinggi, memungkinkan akan memiliki harapan mengenai efikasi diri yang rendah dan sebaliknya ketika seseorang memiliki efikasi diri yang tinggi maka kecemasan, rasa takut, dan stres yang dimiliki seseorang akan menjadi rendah atau berkurang. Sering kali permasalahan yang ada di sekolah dikaitkan dengan Stres Akademik, seperti dalam beberapa penelitian milik Azizah (2016), Wulandari \& Rachmawati (2014), Namira (2018), dan Siregar \& Putri (2019) yang menjelaskan bahwa terdapat hubungan yang signifikan antara efikasi diri dengan stres akademik dan belum banyak penelitian yang mengaitkan antara efikasi dengan stres sekolah. dimana stres akademik sendiri sebenarnya merupakan salah satu sumber dari stres sekolah. 
Peneliti tertarik melakukan penelitian terhadap efikasi diri dengan stres sekolah karena terdapat banyak faktor sumber stres yang dialami siswa di sekolah yang tidak hanya mencakup permasalahan akademik berupa beban atau tugas akademis saja seperti yang telah dijelaskan pada penelitian sebelumnya bahwa masih terdapat faktor kepribaian yakni efikasi diri, dimana efikasi diri dalam proses terjadinya stres yang disebabkan oleh keadaan lingkungan (sekolah) dapat menunjukkan proses terjadinya stres yang berbeda pada setiap individu dimana individu berusaha untuk mengurangi tekanan atau stresor namun memiliki efikasi diri yang rendah akan lebih menemui kesulitan dibandingkan dengan individu yang memiliki efikasi diri yang tinggi (Bartlett 2002). Penelitian ini dapat memberikan manfaat serta informasi bagi para siswa di SMKN 8 Malang mengenai keterkaitan antara efikasi diri dengan stres sekolah. Bagi pihak sekolah, penelitian ini dapat memberikan gambaran mengenai tingkat stres sekolah yang dialami siswanya dan bagaimana meningkatkannya dengan efikasi diri siswa.

\section{METODE}

Penelitian ini merupakan penelitian kuantitatif dengan metode penelitian deskripsi dan korelasional. Variabel bebas yakni efikasi diri dan variabel terikat yakni stres sekolah. Subjek penelitian ini adalah siswa SMKN 8 Malang dengan rentang usia 15 - 19 tahun sejumlah 145 siswa dan berada pada jenjang kelas X - XII. Jumlah total 145 siswa ini terbagi sebanyak 60 siswa untuk uji coba alat ukur sebelum penelitian dan 85 siswa lainnya untuk penelitian yang didapat dengan menggunakan teknik Quota Sampling (Kuota Sampling). Penggunaan tehnik sampling ini berdasarkan pada jumlah sampel yang telah ditentukan oleh peneliti berdasarkan rekomendasi guru SMKN 8 Malang. Dalam penelitian ini teknik pengumpulan data yang dilakukan oleh peneliti yaitu dengan membagikan skala mengenai efikasi diri dan stres sekolah. Pembagian skala ini dilakukan oleh peneliti secara langsung dengan metode turun lapangan.

Dalam penelitian ini, dilakukan uji coba intrumen sebelum penelitian pada subjek penelitian dengan menggunakan instrumen penelitian berupa skala efikasi diri dan stres sekolah. Validitas instrumen dalam penelitian ini menggunakan analisis criterion of internal consistency menurut Likert (dalam Azwar, 2013) criterion of internal consistency merupakan analisis yang diliahat dari seberapa besar koefisien korelasi yang ada dalam pernyataan yang kemudian bersangkutan atau dikaitkan dengan skor total pada skala yang digunakan, dengan teknik yang digunakan berupa korelasi Product Moment Pearson. Validitas skala efikasi diri berkisar antara 0,265-0,628 menunjukkan hasil uji daya beda dengan taraf signifikansi sebesar 5\% $(0,254)$ yang menghasilkan 25 aitem valid dan 11 aitem gugur dari 36 pernyataan dan validitas skala stres sekolah berkisar antara 0, $271-0$, 475 menunjukkan hasil uji daya beda dengan taraf signifikansi sebesar 5\% $(0,254)$ yang menghasilkan 16 aitem valid dan 20 aitem gugur dari 36 pernyataan. Reliabilitas instrument dalam penelitian ini menggunakan bantuan SPSS 25 for windows dengan teknik penghitungan Alpha Cronbach. Skala efikasi diri dengan 25 aitem yang valid memiliki koefisien sebesar 0, 886. Pada skala stres sekolah dengan 16 aitem yang valid menunjukkan hasil koefisien Alpha Cronbach sebesar 0, 786.

Penelitian ini menggunakan analisis deskriptif digunakan oleh peneliti dalam menggambarkan stres sekolah dan efikasi diri pada responden dengan Rumus $T$ score, digunakan untuk mengetahui kategori dan gambaran responden berdasarkan skor skala tinggi, sedang, ataupun rendah yang dilihat berdasarkan skor kelompok. Analisis inferensial juga digunakan dalam analisis data 
penelitian ini untuk mengambil kesimpulan pada uji hipotesis. Uji hipotesis dalam penelitian ini berupa uji korelasi melalui uji asumsi dasar berupa uji normalitas dengan teknik One Sample Kolmogorov-Smirnov, uji linieritas dengan teknik Test for Linierity, dan uji hipotesis dengan teknik analisis korelasi product moment pearson dimana menurut menurut Azwar (2017) Arah hubungan koefisien korelasi kedua variabel dapat dinyatakan dengan tanda positif $(+)$ yang berarti terdapat arah hubungan yang searah dan tanda negatif (-) yang berarti berlawanan arah.

\section{HASIL}

Berdasarkan hasil analisis deskripsi data Efikasi Diri yang diperoleh dari skala efikasi diri sejumlah 25 aitem yang diberikan kepada 85 responden memperoleh nilai rata - rata (Mean) sebesar 78,84 dan standart deviasi sebesar 7,216. Secara umum hasil penelitian menunjukakan bahwa efikasi diri siswa SMKN 8 Malang berada pada kategori rendah. Sebanyak 34/ 40\% siswa menunjukkan tingkat efikasi diri yang rendah, sejumlah 21 / $24,7 \%$ siswa menunjukkan tingkat efikasi diri yang sedang, dan 34/35,3\%. siswa menunjukkan tingkat efikasi diri yang tinggi. Sedangkan pada data stres sekolah analisis daskriptif menunjukkan Deskripsi data Stres Sekolah yang diperoleh dari skala stres sekolah sejumlah 16 aitem yang diberikan kepada 85 responden memperoleh nilai rata rata (Mean) sebesar 39,16 dan standart deviasi sebesar 5,812. Secara umum hasil penelitian menunjukakan bahwa stres sekolah siswa SMKN 8 Malang berada pada kategori tinggi. 35 / 41, $2 \%$ siswa menunjukkan tingkat stres sekolah yang tinggi, sejumlah 20 / 23, $5 \%$ siswa berada pada kategori stres sekolah yang sedang, dan sebanyak 30 / 35, 3 $\%$. siswa menunjukkan tingkat stres sekolah yang rendah.

Berdasarkan hasil analisis inferensial menunjunjukkan bahwa data skala efikasi diri dengan stres sekolah merupakan data yang bahwa kedua data variabel berdistribusi normal dengan signifikansi $>0,05$. Kedua data variabel berdistribusi normal ditujjukkan dengan signifikansi variabel stres sekolah sebesar 0,200 dan signifikansi variabel efikasi diri sebesar 0,055 . Kedua variabel tersebut juga merupakan data yang memiliki hubungan linier ditunjukkan dari diperolehnya nilai signifikansi (Linearity) sebesar 0,00 yang mana nilai tersebut kurang dari 0,05. Berdasarkan uji hipotesis menunjukan bahwa terdapat hubungan negatif yang cukup erat antara efikasi diri dengan stres sekolah. Hal ini berarti apabila siswa SMKN 8 Malang memiliki efikasi diri yang tinggi, maka stres sekolah yang dimiliki rendah. Sebaliknya, apabila siswa SMKN 8 Malang memiliki efikasi diri yang rendah maka stres sekolah yang dimiliki tinggi yang ditunjukkan dengan diperolehnya nilai koefisisen korelasi (rxy) sebesar - 0,504 dengan nilai signifikansi sebesar 0,000 .

\section{PEMBAHASAN}

Berdasarkan dari hasil penelitian yang telah dilakukan menunjukkan bahwa stres sekolah siswa SMKN 8 Malang berada pada kategori tinggi. Hal tersebut dapat dilihat bahwa sebanyak 35 siswa menunjukkan tingkat stres sekolah yang tinggi dengan presentase $41,2 \%$. Sedangkan efikasi diri tergolong rendah, yaitu $40 \%$ siswa. Hal ini dapat timbul sesuai dengan teori Bandura (dalam Feist $\&$ Feist, 2014) yang menjelaskan bahwa pada saat seseorang mengalami kecemasan akut, ketakutan yang kuat, atau tingkat stres yang tinggi, dapat memungkinkan seseorang akan memiliki harapan mengenai efikasi diri yang rendah. Responden penelitian yang sebagian besar merupakan siswa kelas XII dianggap memiliki kesibukan yang lebih tinggi dibandingkan kelas yang lain yakni berupa persiapan kelulusan. Hal tersebut dapat menjadi faktor penyebab rendahnya efikasi diri pada responden penelitian ini. 
Responden penelitian yang cukup besar setelah siswa kelas XII merupakan kelas X yang masih berada pada masa transisi dari Sekolah Menengah Pertama dan memerlukan waktu untuk beradaptasi baik dengan lingkungan sosial sekolah maupun sistem pembelajaran sekolah serta beban tugas yang berbeda dari jenjang sekolah sebelumnya. Hal tersebut dapat menjadi faktor penyebab rendahnya efikasi diri pada responden kelas X. Sedangkan pada responden kelas XI yang mana merupakan jenjang kelas dengan jumlah yang lebih sedikit dibandingkan kelas XII dan kelas X pada penelitian ini dirasa lebih memiliki keyakinan akan kemampuan yang dimilikinya karena pada jenjang kelas XI mereka sudah mampu beradaptasi serta belum terdapat kesibukan yang lebih besar dibandingkan dengan kelas XII berupa persiapan kelulusan.

Siswa SMKN 8 Malang yang memiliki efikasi diri dalam kategori rendah, maka siswa tersebut selain belum dapat memiliki keyakinan atas kemampuan diri yang mereka miliki mereka juga kurang baik dalam mengikuti atau melakukan kegiatan yang ada di sekolah serta dapat mengalami permasalahan berupa timbulnya stres. Selain itu siswa juga akan mengalami kesulitan dalam menemukan jalan keluar atau penyelesaian pada saat menghadapi permasalahan yang sulit. Sedangkan siswa yang memilki efikasi diri yang tinggi memiliki keyakinan terhadap kemampuan diri mereka dan mampu melakukan kegiatan atau ikut serta dalam suatu kegiatan pembelajaran di sekolah dengan baik dan suskses. Siswa dengan efikasi diri yang tinggi juga cenderung akan lebih dapat bertindak dan menjadi sukses dibandingkan dengan siswa yang memiliki efikasi diri yang rendah. Efikasi diri yang rendah pada siswa dapat ditingkatkan dengan pengerjaan tugas dengan tingkat yang berbeda / menantang, guru memberikan scaffolding berupa tambahan waktu khusus (Lodewyk \& Winne dalam
Ormrod, 2009)

Sedangkan hasil penelitian pada stres sekolah menunjukkan tingginya stres sekolah yang dimiliki siswa $41,2 \%$ dapat timbul sesuai dengan teori yang dijelaskan oleh Desmita (2017) bahwa stres sekolah merupakan suatu keadaan tertekan atau perasaan tidak nyaman yang dialami oleh siswa yang memunculkan terjadinya ketegangan fisisk, psikologis, dan perubahan tingkah laku sehingga dapat mempengaruhi prestasi belajar dari siswa. Responden penelitian yang sebagian besar merupakan siswa kelas XII dianggap memiliki tuntutan atau beban yang lebih besar dibandingkan dari siswa pada tingkatkan kelas yang lain yang mana tuntutan atau beban tersebut berupa pembelajaran akademi dan vokasi serta persiapan dalam menyiapkan kelulusan yakni kegiatan pembekalan tambahan, try out, ujian sekolah, dan juga ujian praktek sebagai syarat keulusan. Hal tersebut dapat menjadi salah satu faktor penyebab tingginya stres sekolah pada siswa.

Responden penelitian yang cukup besar setelah siswa kelas XII merupakan siswa kelas $\mathrm{X}$ yang masih berada pada masa transisi dari Sekolah Menengah Pertama dan memerlukan waktu untuk beradaptasi baik dengan lingkungan sosial sekolah maupun sistem pembelajaran sekolah serta beban tugas yang berbeda dari jenjang sekolah sebelumnya. Hal tersebut dapat menjadi faktor penyebab tingginya stres sekolah pada siswa kelas X. Sedangkan pada responden kelas XI dengan jumlah yang lebih sedikit dibandingkan kelas XII dan kelas X pada penelitian ini, dirasa lebih memiliki stres sekolah yang rendah karena siswa pada jenjang kelas XI mereka sudah mampuan dalam beradaptasi dengan tuntutan yang diberikan oleh sekolah serta beradaptasi dengan lingkungan sekolah dibandingkan dengan kelas XII berupa persiapan kelulusan.

Siswa dengan tingkat stres sekolah yang tinggi dapat memberikan dampak yang buruk 
kepada siswa seperti berbicara ataupun menentang dibelakang guru dan membuat kekacauan ataupun canda gurau di dalam kelas. Hal tersebut selaras dengan penelitian yang dilakukan oleh Eldorita \& Layyinah (2016) yang menjelaskan bahwa siswa yang memiliki stres sekolah yang tinggi akan lebih rentan untuk melakukan tindak yang buruk dan dapat mengarah pada tindak bullying. Stres Sekolah dapat diturunkan dengan menciptakan suasana hubungan interpersonal dengan lingkungan sekolah yang memberikan pengaruh terhadap sikap, kepercayaan, niai, motivasi, dan prestasi orang - orang tersebut (Desmita, 2017). Selain itu terdapat program penanggulangan stres dengan teknik cognitive-behavior dalam program terapi dan konseling berupa inokulasi stres.

Berdasarkan hasil yang diperoleh dari analisis uji hipotesis yang menggunakan teknik korelasi product moment pearson menunjukkan hasil bahwa terdapat hubungan antara efikasi diri dengan stres sekolah pada SMKN 8 Malang, dengan angka koefisien korelasi sebesar - 0, 504. Hal ini berarti bahwa terdapat hubungan yang cukup erat dengan arah hubungan yang negative antara efikasi diri dan stress sekolah, yang selaras dengan penelitian - penelitian yang ada sebelumnya. Hasil penelitian ini sesuai dengan hasil penelitian dari Azizah (2016), Wulandari \& Rachmawati (2014), Namira (2018), dan Siregar \& Putri (2019) yang mana pada beberapa penelitiian tersebut sama sama menunjukkan bahwa hasil penelitian efikasi diri dengan stres akademik memiliki hubungan yang signifikan dimana arah hubungan yang terdapat diantara variabel merupakan hubungan yang negatif atau hubungan yang berlawanan arah. Hal tersebut juga mendukung hasil penelitian ini bahwa ternyata sebagian besar stres sekolah terbentuk dari stres akademik sehingga efikasi diri dengan stres sekolah memiliki hubungan yang signifikan.
Hasil dalam penelitian ini berupa hubungan yang negatif dimana efikasi diri rendah dan stres sekolah yang tinggi, sesuai dengan teori Bandura (dalam Feist \& Feist, 2014) yang menjelaskan apabila seseorang mengalami kecemasan akut, ketakutan yang kuat, atau tingkat stres yang tinggi, memungkinkan akan memiliki harapan mengenai efikasi diri yang rendah. Efikasi diri yang rendah akan membuat siswa kesulitan dalam memecahkan suatu permasalahan ataupun mencari jalan keluar dalam suatu masalah yang dapat menimbulkan stres. Sedangkan efikasi diri yang tinggi dapat membuat siswa melakukan suatu aktivitas atau perilaku tertentu dengan sukses. Efikasi diri dalam proses terjadinya stres sekolah dapat menunjukkan proses terjadinya stres yang berbeda pada setiap individu dimana individu berusaha untuk mengurangi tekanan atau stresor namun memiliki efikasi diri yang rendah akan lebih menemui kesulitan dibandingkan dengan individu yang memiliki efikasi diri yang tinggi (Bartlett 2002). Berdasarkan hal tersebut menunjukkan bahwa terdapat siswa yang mengelami stres sekolah yang tinggi, sedang dan rendah berdasarkan dari keterkaitan dengan aspek kepribadian yang mereka miliki yaitu berdasarkan tingkat efikasi diri yang dimiliki oleh siswa.

Berdasarkan data awal yang menunjukkan bahwa sebagaian besar jumlah responden lebih banyak pada siswa kelas XII yang mana siswa kelas XII dapat dikatakan memiliki tuntutan ataupun beban yang lebih besar dibandingkan dengan siswa kelas $\mathrm{X}$ atau XI yakni berupa persiapan kelulusan. Stres sekolah yang tinggi dan efikasi diri yang rendah pada SMKN 8 Malang ternyata tidak merubah prestasi yang dimiliki oleh sekolah tersebut karena pengondisian displin yang diterapkan oleh sekolah. Sehingga siswa dalam sekolah tersebut dapat melakukan kegiatan belajar disekolah, kegiatan ekstrakulikuler, dan kegiatan yang lainnya di 
sekolah dapat dikatakan bahwa sebagian besar bukan dilakukan karena mereka merasa yakin dengan kemampuan yang mereka miliki melainkan lebih kepada tuntutan yang diberikan oleh guru dan sekolah berupa kewajiban berprestasi dalam bidang akademik dan non akademik serta mampu menguasai teknologi terkini juga memiliki autosoftskill serta adanya jadwal sekolah yang ketat.

\section{KESIMPULAN}

Berdasarkan dari hasil yang telah didapatkan dalam pembahasan sebelumnya, maka dapat disimpulkan bahwa pada sebagian besar siswa SMKN 8 Malang memiliki stres sekolah pada kategori yang tinggi yang berarti siswa mengalami keadaan yang tertekan dan mengalami kesulitan dalam beradaptasi dengan lingkungan sosial sekolah. Ditemukan pula bahwa pada sebagian besar siswa SMKN 8 Malang memiliki efikasi diri pada kategori yang rendah yang berarti siswa belum memiliki keyakinan akan kemampuan yang mereka miliki.

Dalam penelitian ini menunjukkan bahwa dalam penelitian ini terdapat hubungan signifikan yang cukup erat dengan arah hubungan yang negatif antara efikasi diri dengan stres sekolah pada siswa SMKN 8 Malang, hal tersebut berarti semakin tinggi efikasi diri yang dimiliki siswa maka semakin rendah stres sekolah yang dimiliki siswa dan juga sebaliknya, semakin tinggi stres sekolah yang dimiliki siswa maka semakin rendah efikasi diri yang dimiliki siswa.

\section{DAFTAR RUJUKAN}

Azizah, N. L. 2016. Hubungan Dukungan Sosial Dan Efikasi Diri Terhadap Stres Akademik Pada Mahasiswa Baru Fakultas Psikologi UIN Malang Angkatan 2015. Skripsi. Tidak Diterbitkan. Fakultas Psikologi. Universitas Islam Negeri Maulana Malik Ibrahim : Malang.
Azwar, S. 2013. Sikap Manusia Teori Dan Pengukurannya. Yogyakarta : Pustaka Pelajar.

\section{Azwar, S. 2017. Metode Penelitian Psikologi} Edisi II. Yogyakarta : Pustaka Pelajar.

Bartlett, D. 2002 Stress Perspectives and Processes. Buckingham : Open University Press.

Bethune, S. April 2014. Teen Stress Rivals That Of Adult APAs Stress in America $^{\mathrm{TM}}$ survey finds unhealthy behavior in teens, especially during the school year. Apa.org. (Online). (https:// www.apa.org/monitor/2014/04/teenstress), diakses 07 Oktober 2019

Desmita. 2017. Psikologi Perkembangan Peserta Didik Panduan Bagi Orang Tua dan Guru Dalam Memahami Psikologi Anak Usia SD, SMP, dan SMA. Bandung : PT Remaja Rosdakarya.

Eldorita, I \& Layyinah. 2016. Effect Of Social Competence And School Stress On Bullying Behaviour In Adolescent. Journal Of Psychology. Vol. 4 No. 1

Feist J, \& Greorgy J. F. (2014). Teori Kepribadian : Theories Of Personality Edisi 7 Buku 2. Jakarta : Salemba Humanika

Ihsanuddin. 06 September 2017. Ini Perbedaan Aturan Hari Sekolah Pada Permendikbud Dan Perpres.

Kompas.com. (Online).

(https://nasional.kompas.com/ $\mathrm{read} / 2017 / 09 / 06 / 14562281 /$ iniperbedaan- aturan-hari-sekolah-padapermendikbud-dan-perpres?page $=$ all) diakses 17 Oktober 2019

Kemdikbud. 2015. 503 Daftar Sekolah dengan Indeks Integritas Tertinggi. Kemdikbud.go.id.(Online).(https:// www.kemdikbud.go.id/main/ 
8 | Putri \& Tantiani - Peran Self-Efficacy pada...

blog/2015/12/503-daftar-sekolah-

dengan-indeks-integritas-tertinggi--

4942-4942), diakses 20 November

2019.

Maharani, Esthi. 04 Maret 2015. Psikolog :

44 Persen Remaja Stres Hadapi

Ujian.Republika.co.id.(Online).(https://

republika.co.id/berita/pendidikan/

eduaction/15/03/04/nkoeff- psikolog-44

-persen-remaja-stre s-hadapi-ujian), diakses 17 Oktober 2019.

Namira. R. 2018. Hubungan Antara SelfEfficacy Dengan Stres Akademik Pada Remaja Sma Di Yogyakarta. Skripsi. Tidak Diterbitkan. Fakultas Psikologi Dan Ilmu Budaya. Universitas Islam Indonesia : Yogyakarta

Ormrod, E. J. 2009. Edisi Keenam Psikologi Pendidikan Membantu Siswa Tumbuh dan Berkembang Jilid 2. Jakarta : Erlangga

Siregar, K. I \& Sefni R. P. 2019. Hubungan Self-Efficacy dan Stres Akademik Mahasiswa. Vol 6 No 2.

Wulandari \& Rachmawati. 2014. Efikasi Diri Dan Stres Akademik Pada Siswa Sekolah Menengah Atas Program Akselerasi. Journal of Psychology. Vol 19 (2), 1-10. 